OPEN ACCESS

Edited by:

Zhang Chengjun,

Lanzhou University, China

Reviewed by:

Yanzhong Wang,

China University of Petroleum,

(East China) China

Meiyan Fu,

Chengdu University of Technology,

China

*Correspondence:

Lewei Hao

Iwhao@/zb.ac.cn

Huifei Tao

tophic3@yeah.net

Specialty section:

This article was submitted to

Sedimentology, Stratigraphy and

Diagenesis,

a section of the journal

Frontiers in Earth Science

Received: 29 November 2021

Accepted: 18 January 2022

Published: 21 February 2022

Citation:

Hao L, Tao H, Li S, MaX, Ji H and Qiu J (2022) Distribution and Controlling Growth Factors of Ooids in Qinghai Lake, Northern Tibet Plateau, China.

Front. Earth Sci. 10:824453.

doi: 10.3389/feart.2022.824453

\section{Distribution and Controlling Growth Factors of Ooids in Qinghai Lake, Northern Tibet Plateau, China}

\author{
Lewei Hao ${ }^{1 *}$, Huifei Tao ${ }^{1 *}$, Shutong $\mathrm{Li}^{1}$, Xiaofeng $\mathrm{Ma}^{1}{ }^{1}$, Hongjie $\mathrm{Ji}^{2}$ and Junli Qiu ${ }^{1}$ \\ ${ }^{1}$ Key Laboratory of Petroleum Resources, Northwest Institute of Eco-Environment and Resources, Chinese Academy of \\ Sciences, Lanzhou, China, ${ }^{2}$ State Key Laboratory for Nuclear Resources and Environment, East China University of Technology, \\ Nanchang, China
}

Ooids are coated carbonate grains, which exist in shallow water marine and lacustrine environments. There is an ongoing debate about whether the origin of ooids is inorganic or organic. Qinghai Lake is the largest inland lake in China, and ooids are seen on the lake shore. This paper focuses on whether environmental energy has an impact on the growth and size of ooids. Through hydrochemical analysis, thin section observation, and scanning electron microscope, the carbonate coats of beach sands from Qinghai Lake were studied. The research shows that the carbonate-coated grain content from the different shores of the lake present variations. The hydrodynamics and particularly the waves seem to control the distribution of carbonate coats in the lake shore, not the hydrochemical condition. In addition, the integrity and thickness of carbonate coats from the shores with a strong hydrodynamic force are high and thick, respectively. The carbonate coats are often observed on medium-grained sands, and the maximum carbonate-coated grain occurred under the strongest waves, indicating that ooids can be produced only when hydrodynamic force and particle size are well matched. Bacteria or extracellular polymeric substances are not observed within the ooid cortices by scanning electron microscopy. So, bacteria may not be a major factor in the formation and growth of ooids, but hydrodynamic forces appear to play a great role in carbonate grain coat distribution, integrity, thickness, and ooid grain size.

Keywords: Qinghai Lake, hydrodynamics, grain size, hydrochemical condition, carbonate coats

\section{INTRODUCTION}

Ooids are poorly to well-developed cortices accreted around a nucleus, which are found in both ancient and modern sedimentary environments (Ball, 1967; Harris et al., 1979; Beukes, 1983; Simonson and Jarvis, 1993; Li et al., 2013; Liu et al., 2021). Ooids have been used as paleoclimatic and paleoceanographic proxies for sea level, redox state, water depth, temperature, salinity, and hydrodynamic environment (Kump and Hine, 1986; Opdyke and Wilkinson, 1990; Lu et al., 2020). It has been debated for over a hundred years whether the formation of ooids is inorganic or organic. The most widely accepted ooid genesis is that ooids are inorganic carbonates formed by chemical precipitation from shallow, warm, carbonate-saturated, and agitated water (Davies et al., 1978; Tucker and Wright, 1990; Sumner and Grotzinger, 1993; Duguid et al., 2010; Trower et al., 2017). Field and laboratory studies suggest that tangential ooids are inorganic precipitated during agitated conditions, whereas radial ooids are formed in quiet water with the participation of organic 


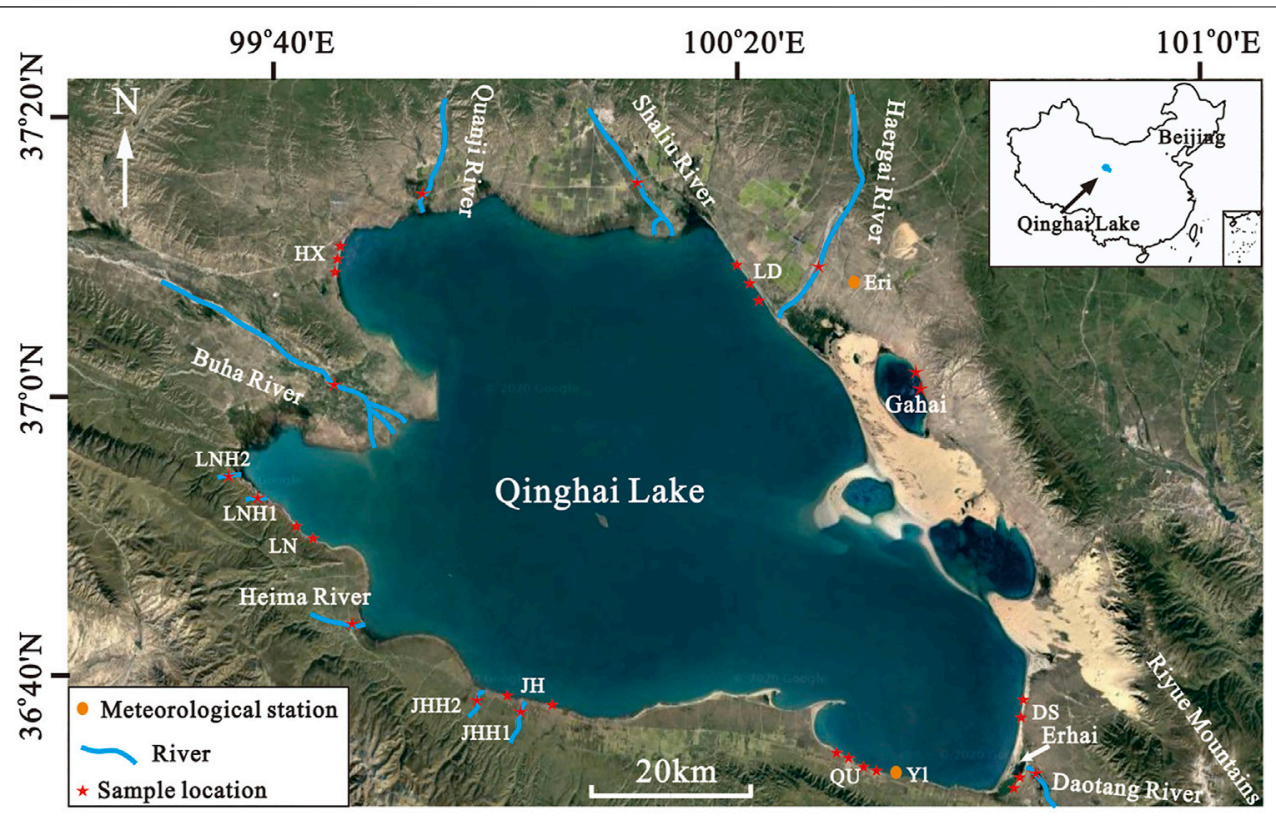

FIGURE 1 | Location of the study area (satellite data taken from Google Earth).

matter (Kahle, 1974; Davies and Martin, 1976; Davies et al., 1978; Diaz and Eberli, 2019). Microbes may be a key role in the formation of ooids. Metabolic activities of microbes induce $\mathrm{pH}$ changes resulting in precipitation and extracellular polymeric substances (EPS) providing nucleation sites for carbonate mineral growth (Dupraz and Visscher, 2005; Diaz and Eberli, 2019). Photosynthetic microbes not only dominate carbonate precipitation in the early stages of ooids but also control the formation of the entire cortex in ooids from Lake Geneva (Plée et al., 2008; Pacton et al., 2012). Microorganisms are found to be important in the formation of ooids. However, Trower et al. (2017) demonstrated that the physical environment is more important generally in controlling ooid growth in laboratory experiments. The size of ooids is determined by a balance between growth by chemical precipitation and erosion by abrasion (Trower et al., 2017; Sipos et al., 2018). This oratory result lacks validation with field data (Diaz and Eberli, 2019). Ariztegui et al. (2012) also showed a little influence of environmental energy on the size and form of the ooids in western Lake Geneva, Switzerland. So, whether the environmental energy has an impact on the growth of ooids needs more field data.

Most of the studies on modern ooids are concentrated in the ocean especially the Bahamian archipelago, which have been extensively studied (Ball, 1967; Harris et al., 1979; Wanless and Tedesco, 1993; Rankey et al., 2006; Harris et al., 2011). Besides the ocean, ooids are also found in lakes, such as the Great Salt Lake, Utah (Kahle, 1974; Halley, 1977), Pyramid Lake, Nevada (Popp and Wilkinson, 1983), Higgins Lake, Michigan (Wilkinson et al., 1980), and Lake Geneva, Switzerland (Davaud and Girardclos, 2001; Plée et al., 2008; Pacton et al., 2012). Most of these lacustrine ooids show a smaller size compared with the ocean and some particles with discontinuous or patchy micritic coatings (Davaud and Girardclos, 2001). In the Qinghai Lake located in the northeastern Tibetan Plateau (Figure 1), aragonitic ooids are found in the eastern lake shore (LZIG, 1979). However, further works about the origin, distribution, and morphology of ooids in Qinghai Lake have not been studied. The aims of this paper are to describe the distribution of the coated grains in Qinghai Lake and analyze the factors controlling their distribution and growth, especially environmental energy.

\section{Study area}

Qinghai Lake is the largest inland saltwater lake in China, which is located in the northeastern Tibetan Plateau $\left(36^{\circ} 32^{\prime}-37^{\circ} 15^{\prime} \mathrm{N}\right.$, $99^{\circ} 36^{\prime}-100^{\circ} 47^{\prime} \mathrm{E}$ ) (Figure 1). It is a closed lake with an area of $4,400 \mathrm{~km}^{2}$ and a catchment area of $c a 2.96 \times 10^{4} \mathrm{~km}^{2}$ (Fan et al., 1994). The salinity is from 12.25 to $13.2 \mathrm{~g} / \mathrm{L}$, and the south of the lake is higher than the northern lake (LZIG, 1979). The lake transformed from open to close due to the tectonic uplift of the Riyue Mountains during the Middle to Late Pleistocene ( $\mathrm{Li}$ and Fang, 1999; Yuan et al., 1990). Qinghai Lake is situated in a semiarid area influenced by the East Asian monsoon, Indian monsoon, and westerly winds (An et al., 2012). The average annual temperature is $-0.7^{\circ} \mathrm{C}$, and the average water depth is $21 \mathrm{~m}$ in the lake (Fan et al., 1994). The main rivers flowing into Qinghai Lake are Buha River, Quanji River, Shaliu River, Haergai River, and Heima River, and the other rivers are small and seasonal (Figure 1) (LZIG, 1979; Li et al., 2007). The two meteorological stations Eri and $\mathrm{Yl}$ are located in the north and south of the lake, respectively (Figure 1). Eri Station located in the northern lake displays a bidirectional wind regime, and the wind predominantly blows from ESE and NE. The mean wind speed is $4.6 \mathrm{~m} / \mathrm{s}$ (Hu et al., 2021). The prevailing winds at Yl Station located in the 
TABLE 1 | Hydrochemical properties and major chemical constituents of water samples from the study area (ionic concentrations in mg/L).

\begin{tabular}{|c|c|c|c|c|c|c|c|c|c|c|c|}
\hline $\begin{array}{l}\text { Sample } \\
\text { type }\end{array}$ & Sample & $\mathrm{Ca}^{2+}$ & $\mathbf{K}^{+}$ & $\mathrm{Mg}^{2+}$ & $\mathrm{Na}^{+}$ & $\mathrm{Cl}^{-}$ & $\mathrm{SO}_{4}{ }^{2-}$ & $\mathrm{CO}_{3}{ }^{2-}$ & $\mathrm{HCO}_{3}{ }^{-}$ & pH & $\mathbf{S}$ \\
\hline \multirow[t]{10}{*}{ River } & $\mathrm{BHH}$ & 38.75 & 1.98 & 15.66 & 30.00 & 32.39 & 53.62 & 2.89 & 176.10 & 8.21 & - \\
\hline & DTH & 66.96 & 7.17 & 36.96 & 99.33 & 132.48 & 72.30 & 17.32 & 346.34 & 8.43 & - \\
\hline & HEG & 56.43 & 1.88 & 22.69 & 31.35 & 14.58 & 43.29 & 17.32 & 193.71 & 8.37 & - \\
\hline & $\mathrm{HMH}$ & 29.58 & 3.25 & 13.38 & 52.17 & 30.02 & 22.77 & 5.77 & 205.45 & 8.44 & - \\
\hline & $\mathrm{JHH} 1$ & 74.55 & 2.58 & 9.73 & 32.58 & 20.01 & 29.94 & 5.77 & 217.19 & 8.38 & - \\
\hline & $\mathrm{JHH} 2$ & 55.62 & 3.66 & 7.75 & 30.51 & 22.77 & 22.86 & 5.77 & 146.75 & 8.30 & - \\
\hline & LNH1 & 78.00 & 2.02 & 21.21 & 42.63 & 48.69 & 28.29 & 5.77 & 281.77 & 8.32 & - \\
\hline & LNH2 & 72.39 & 3.45 & 18.00 & 39.66 & 43.41 & 45.06 & 8.66 & 211.32 & 8.34 & - \\
\hline & QJH & 62.88 & 2.24 & 13.35 & 32.04 & 23.73 & 26.64 & 5.77 & 199.58 & 8.36 & - \\
\hline & SLH & 27.00 & 1.89 & 14.99 & 75.33 & 35.94 & 96.24 & 5.77 & 187.84 & 8.37 & - \\
\hline \multirow[t]{17}{*}{ Lake } & DS1 & 8.23 & 160.56 & 688.20 & $2,480.54$ & $4,602.00$ & $1,922.40$ & 288.70 & 851.17 & 8.87 & 11.84 \\
\hline & DS2 & 7.23 & 160.62 & 706.20 & $2,490.48$ & $4,765.80$ & $1,960.20$ & 288.70 & 851.17 & 8.86 & 10.18 \\
\hline & $\mathrm{HX}_{1}$ & 6.38 & 156.72 & 679.80 & $2,830.22$ & $4,486.80$ & $1,860.60$ & 317.57 & 836.49 & 8.94 & 10.02 \\
\hline & HX2 & 7.87 & 162.00 & 721.20 & $2,903.49$ & $5,092.20$ & $2,148.60$ & 317.57 & 821.82 & 8.95 & 11.34 \\
\hline & HX3 & 8.26 & 142.20 & 607.20 & $2,568.00$ & $4,066.20$ & $1,710.00$ & 317.57 & 821.82 & 8.91 & 14.20 \\
\hline & $\mathrm{JH1}$ & 6.59 & 118.32 & 472.20 & $2,247.76$ & $3,290.40$ & 1,396.20 & 288.70 & 777.79 & 8.90 & 12.43 \\
\hline & $\mathrm{JH} 2$ & 6.58 & 119.40 & 452.80 & $2,264.74$ & $2,079.00$ & 931.20 & 303.13 & 719.09 & 8.98 & 15.58 \\
\hline & LD1 & 9.54 & 104.04 & 430.50 & $2,118.60$ & $3,911.40$ & $1,639.20$ & 274.26 & 704.41 & 9.04 & 16.35 \\
\hline & LD2 & 9.35 & 127.44 & 505.74 & $2,192.40$ & $2,698.20$ & $1,171.20$ & 274.26 & 645.71 & 9.00 & 18.04 \\
\hline & LD3 & 10.15 & 121.50 & 530.58 & $2,176.20$ & $3,381.60$ & $1,430.40$ & 274.26 & 645.71 & 9.02 & 17.71 \\
\hline & LN1 & 7.08 & 192.72 & 765.60 & $2,725.00$ & $4,813.80$ & $1,971.00$ & 346.44 & 763.12 & 8.99 & 11.40 \\
\hline & LN2 & 5.44 & 164.52 & 738.00 & 2,390.94 & $4,686.60$ & 1,899.00 & 360.87 & 733.77 & 9.03 & 9.55 \\
\hline & LN3 & 7.48 & 113.28 & 486.54 & $1,936.80$ & $3,057.00$ & $1,261.20$ & 245.39 & 851.17 & 8.84 & 12.71 \\
\hline & QU1 & 9.14 & 107.58 & 459.30 & $1,792.20$ & $2,878.80$ & $1,182.60$ & 332.00 & 821.82 & 8.96 & 21.76 \\
\hline & QU2 & 5.67 & 132.96 & 577.74 & 2,364.00 & $3,531.00$ & $1,447.80$ & 332.00 & 821.82 & 8.94 & 11.20 \\
\hline & QU3 & 9.31 & 125.82 & 520.38 & $2,183.40$ & $3,816.00$ & 1,609.20 & 317.57 & 821.82 & 8.97 & 17.58 \\
\hline & QU4 & 5.99 & 117.00 & 507.12 & $2,067.60$ & $3,292.20$ & $1,380.60$ & 346.44 & 821.82 & 8.95 & 13.35 \\
\hline \multirow[t]{4}{*}{ Lagoon } & $\mathrm{EH} 1$ & 24.19 & 13.32 & 76.14 & 273.06 & 120.84 & 57.78 & 34.64 & 363.95 & 8.63 & 25.86 \\
\hline & $\mathrm{EH} 2$ & 35.20 & 11.95 & 60.20 & 226.66 & 186.12 & 112.14 & 28.87 & 363.95 & 8.43 & 30.97 \\
\hline & $\mathrm{GH} 1$ & 13.89 & 405.33 & 985.86 & $6,780.89$ & $10,160.40$ & $4,645.80$ & 433.04 & 807.14 & 8.89 & 14.01 \\
\hline & $\mathrm{GH} 2$ & 13.21 & 442.87 & $1,154.17$ & $6,986.84$ & 8,295.60 & $3,856.80$ & 447.48 & 792.47 & 8.90 & 14.72 \\
\hline
\end{tabular}

Note. S, calcium carbonate supersaturation value.

southern lake are from NNE and NE, and the mean wind speed is $3.7 \mathrm{~m} / \mathrm{s}$ (Li et al., 2016, Li et al., 2018; Li, 2020). Wave height and length in coastal systems correspond to wind speed and fetch in lakes. Annual average wave height of Qinghai Lake is from 0.2 to $0.4 \mathrm{~m}$ according to the wind speed from 2.8 to $4.1 \mathrm{~m} / \mathrm{s}$ (Zhang et al., 2018). Based on the wind data, it shows that the hydrodynamics of the northern lake are stronger than the southern lake. Two lagoons are distributed on the east coast of the lake, named Erhai and Gahai, respectively (Figure1). There are rivers flowing into Erhai, while Gahai is a closed lagoon. The area of Erhai and Gahai are 4 and $12 \mathrm{~km}^{2}$, respectively. The maximum depths of the lagoon are from 4 to $5 \mathrm{~m}$ (LZIG, 1979). Due to the small area and shallow water depth, the waves formed in the lagoon are small. Beach deposits occur mostly along the coast of the lake and lagoons.

\section{METHODS}

A total of 31 water and sediment samples are collected from the lake and rivers. Among them, 10 samples are distributed in 10 rivers, 17 samples from 6 beaches of a lake (DS, HX, JH, LD, LN, QU), and 4 in the beaches of two lagoons (Figure 1 and Table 1). All water samples were filtered by $0.45-\mu \mathrm{m}$ membranes. The bottles were rinsed twice with deionized water and local water before sampling. The concentrations of major cations and anions were detected by ICP-OES (OPTIMA 8000, PerkinElmer) and ion chromatography (ECO IC, Metrohm), respectively. Carbonate and bicarbonate ions were measured by titration method according to the geological and mineral industry standard of the People's Republic of China (DZ/T 0064.49-93: Groundwater quality analysis methods Part 49: Determination of carbonate, bicarbonate and hydroxide ions-Titration method). $\mathrm{pH}$ values were measured with handheld meters (SX-620; Sanxin, China). Sixteen sediment samples were selected from eight rivers, six beaches of lake and two lagoons for thin sections. The samples were obtained under polarization microscope with the photocollecting system. The grains with carbonate coats are mostly smaller than $500 \mu \mathrm{m}$. On the basis of the analysis of thin sections, eight sediment samples with carbonate coats were selected and sieved less than $500 \mu \mathrm{m}$ for scanning electronic microscopy (SEM) analysis. The samples were impregnated with epoxy resin for thin sections with a diameter of $1 \mathrm{~cm}$ and a thickness of $3 \mathrm{~mm}$. The thin sections were mounted on an aluminum stub and coated with carbon to render them conductive. Samples were imaged using a Zeiss MERLIN Compact FESEM. The grain size and carbonate-coated thickness in every photomicrograph by SEM was obtained using the ImageJ software. The roundness of 


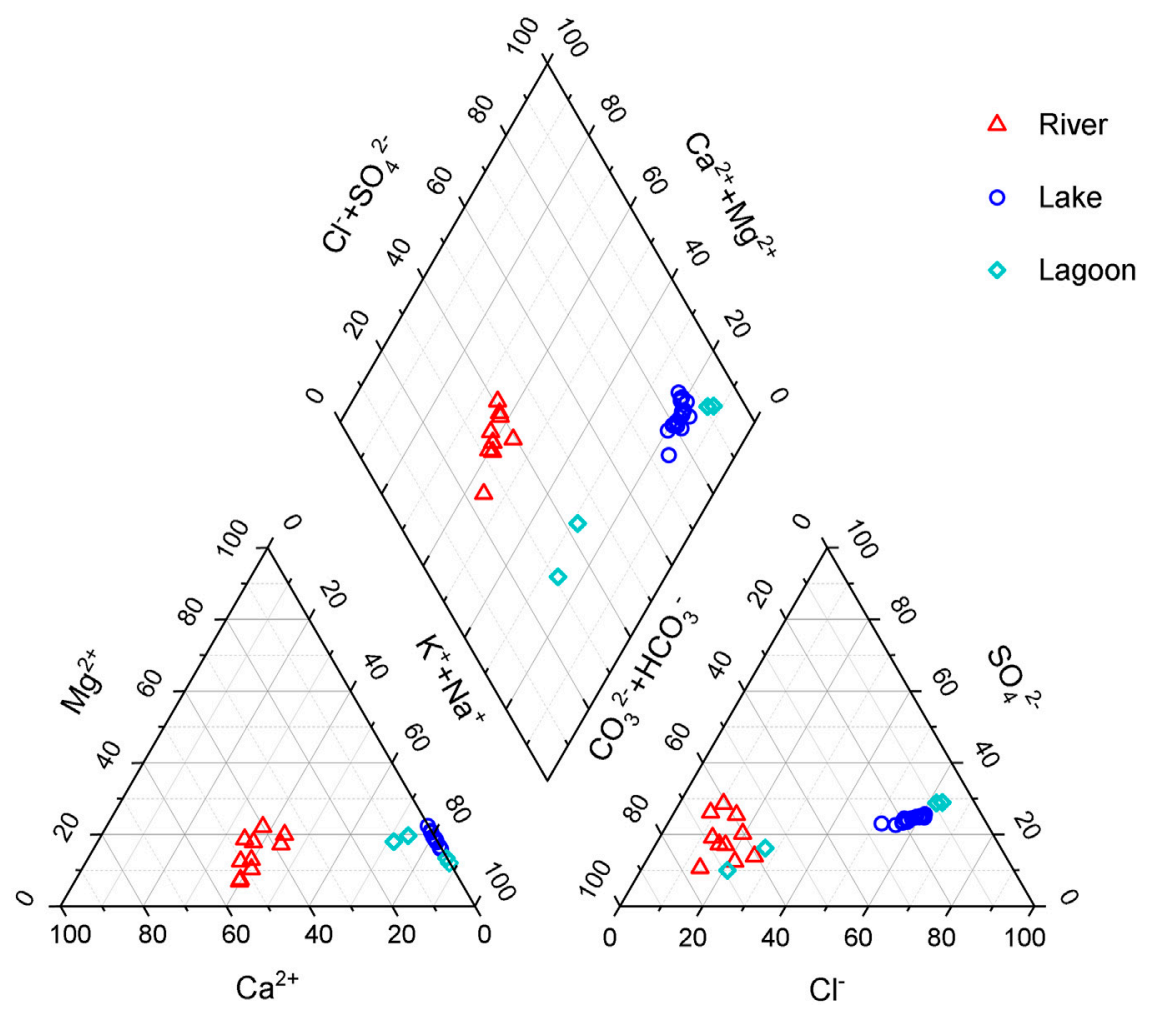

FIGURE 2 | Piper diagram plot for the study area (Piper, 1944).

the grains with carbonate coats was classified as 1 (angular), 2 (sub-angular), 3 (sub-rounded), 4 (rounded), and 5 (very rounded) using the scale from the petroleum and natural gas industry standards of the People's Republic of China (SY/T 53682016: Identification for thin section of rocks). The proportion of carbonate coat covering the grain surface was described by a semiquantitative approach, from 1 (10\% grain surface) to 10 (100\% of grain surface).

\section{RESULTS}

\section{Hydrochemical characteristics of water}

Hydrochemical data of water samples are presented in Table 1. It shows that the concentrations of most ions in lakes are generally higher than those in rivers, except calcium ion. The concentrations of ions in a lagoon with river inflow (EH1 and $\mathrm{EH} 2$ ) are between those of lakes and rivers (Table 1). Water samples in the closed lagoon (Gahai) present the highest the concentrations of ions in this study area. Figure 2 shows the Piper diagram plot for the study area. Water samples are classified as two different water types. The hydrochemical types of most waters in the rivers are $\mathrm{HCO}_{3}-\mathrm{Ca} \cdot \mathrm{Na}$ type. Water samples from the lake and closed lagoon present the $\mathrm{Cl}-\mathrm{Na}$ type. Water samples of a lagoon with a river inflow show the $\mathrm{HCO}_{3}-\mathrm{Na}$ type. The $\mathrm{pH}$ values in the rivers range 8.21-8.44. The lake water samples present higher $\mathrm{pH}$ values, from 8.84 to
9.04 (Table 1). For the lagoons, one with a river inflow shows lower $\mathrm{pH}$ values than the other.

\section{Characteristics of carbonate coats}

Through thin section observation, carbonate coats are found in lake and lagoon sediments, while there are no carbonate coats on grains in river sediments (Figure 3A). Carbonate coats cover diverse framework grains (e.g., quartz, feldspars, heavy minerals, lithic fragments, and carbonates) in different samples, reflecting the nature of the source areas. Some particles exhibit patchy or discontinuous coatings, and other grains present continuous cortices with poorly developed concentric laminae (Figures 3B-D), similar to lacustrine ooids described from Lake Geneva (Davaud and Girardclos, 2001). Scanning electron microscopy analyses reveal needle-columnar and anhedral crystals within the cortices (Figures 3E,F). The number of particles with carbonate coats, the degree of carbonate coat coverage, and thickness of coats are highly variable in the sediments. The carbonate coat thickness, coverage, particle size, and roundness of nine sediment samples from lakes and lagoons were statistically analyzed (Table 2). In total, 117 to 242 grains were counted to identify whether carbonate coats are developed in the samples. The sediment samples show significant differences in the percentage of particles with carbonate coats. The lagoon sediments have low values of $15.3 \%$ and $15.8 \%$ (Table 2). Compared with lagoons, the percentage of particles with carbonate coats in the lake 

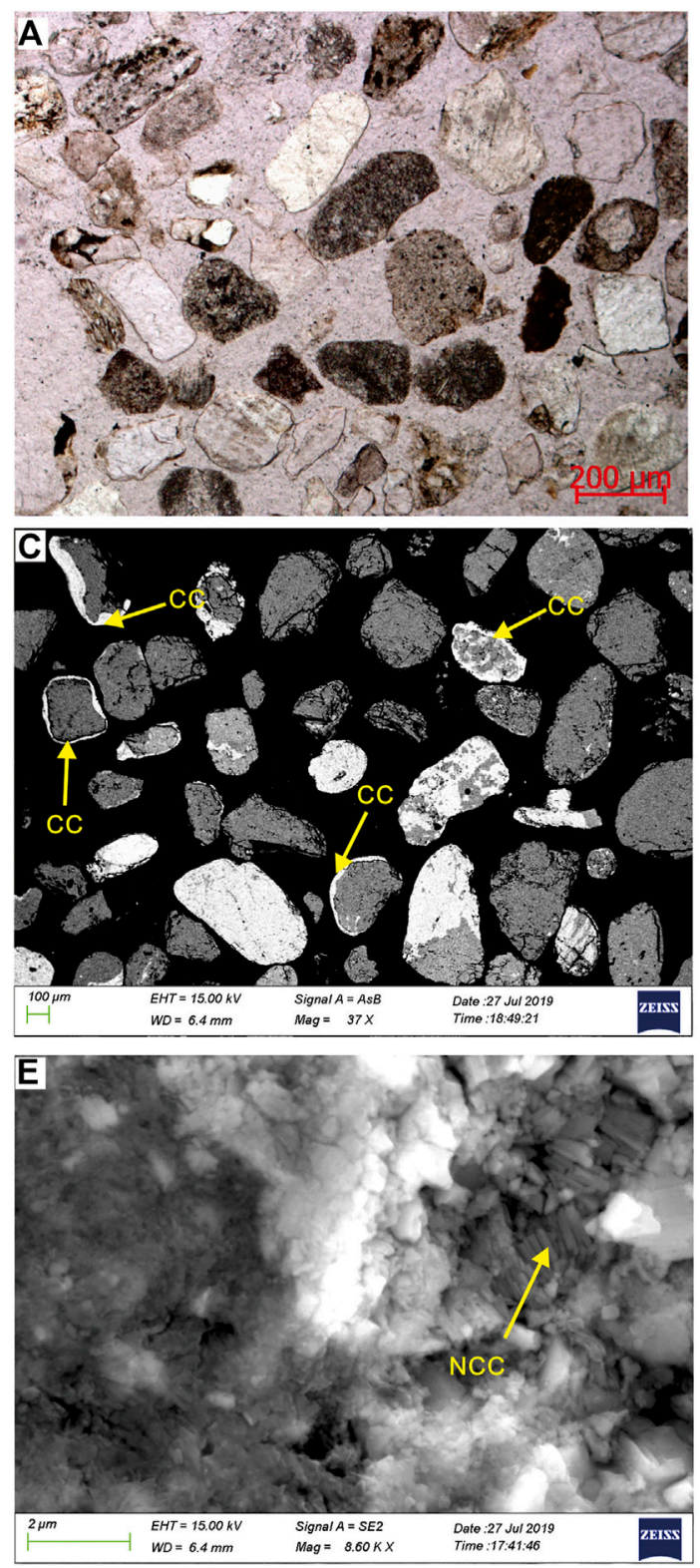
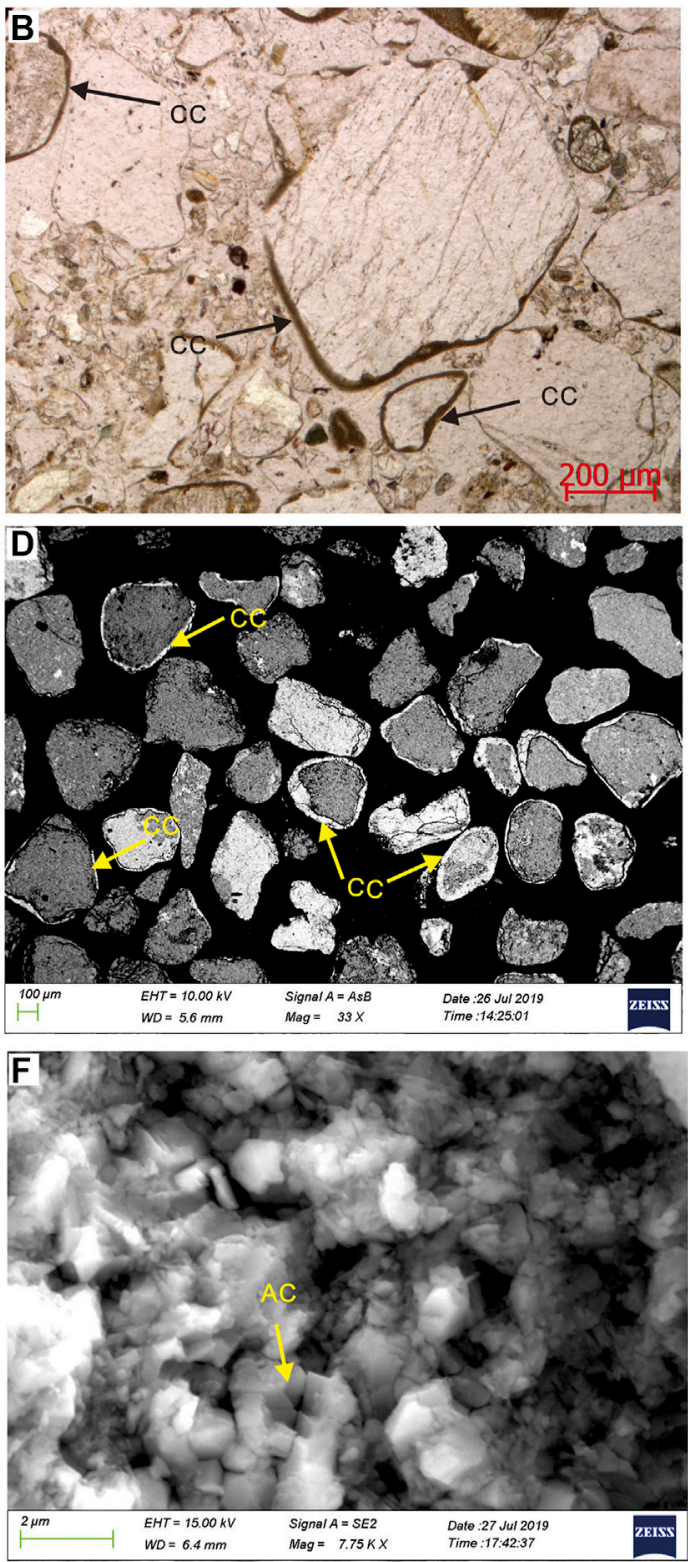

FIGURE 3 | Representative microphotographs under optical microscope and scanning electronic microscopy (SEM) showing the textural characteristics of carbonate coats within the study area. (A) Photomicrograph of the sand sediments from Buha River. (B) Photomicrograph of the sample QU4, CC-carbonate coat. (C) SEM image of the sample HX4. (D) SEM image of the sample LD1. (E) SEM image reveals needle-columnar crystals within the cortices. NCC, needle-columnar crystals. (F) SEM image reveals anhedral crystals within the cortices. AC, anhedral crystals.

sediments have higher values, but there are also differences between the northern and southern parts of the lake. In the northern lake, the percentage of particles with carbonate coats ranges from $26.1 \%$ to $43.1 \%$. The particles with carbonate coat percentages of two samples in the south of the lake are $20.7 \%$ and $29.0 \%$, respectively (Table 2 ).

The grain sizes of all samples display mean values ranging from 173.7 to $303.5 \mu \mathrm{m}$ (Table 2). The sediments of samples belong to fine sand $(125-250 \mu \mathrm{m})$ and medium sand $(250-500 \mu \mathrm{m})$. DS2 and HX4 consist of fine sand (Figure 4A). LN3 and EH1 are mainly medium sand (Figure 4A). The other samples include fine sand and medium sand (Figure 4A). To the particles with carbonate coats, they are mainly distributed in the coarser part of the samples (Figure 4B). The grain size of the particles with carbonate coats from the samples presents mean values ranging from 178.8 to $372.3 \mu \mathrm{m}$ (Table 2). The particles with carbonate coats are mainly composed of medium sand except samples DS2 and HX4 (Figure 4B).

The roundness of the particles with carbonate coats shows mean values ranging from 2.9 to 3.9 (Table 2). The particle roundness from QU4 and EH1 present sub-angular to rounded. The other samples are mainly sub-rounded to even very rounded 
TABLE 2 | Data table for the samples from the lake and lagoon.

\begin{tabular}{|c|c|c|c|c|c|c|c|c|c|}
\hline $\begin{array}{l}\text { Sampling } \\
\text { location }\end{array}$ & Sample & N1 & N2 & $\mathbf{P}$ & D1 & D2 & $\mathbf{R}$ & I & $\mathbf{T}$ \\
\hline \multirow[t]{2}{*}{ South of the lake } & QU4 & 184 & 38 & 20.7 & 233.9 & 290.0 & 3.0 & 5.8 & 15.4 \\
\hline & DS2 & 214 & 62 & 29.0 & 173.7 & 198.8 & 3.6 & 6.8 & 11.6 \\
\hline \multirow[t]{4}{*}{ North of the lake } & $\mathrm{HX} 4$ & 230 & 60 & 26.1 & 185.9 & 210.7 & 3.8 & 7.0 & 11.4 \\
\hline & $\mathrm{JH} 2$ & 242 & 88 & 36.4 & 222.5 & 276.2 & 3.6 & 7.7 & 12.8 \\
\hline & LD1 & 117 & 44 & 37.6 & 281.2 & 372.3 & 3.5 & 7.7 & 18.8 \\
\hline & LN3 & 209 & 90 & 43.1 & 277.1 & 336.1 & 3.6 & 7.5 & 13.3 \\
\hline \multirow[t]{2}{*}{ Lagoon } & $\mathrm{EH} 1$ & 124 & 19 & 15.3 & 303.5 & 321.5 & 2.9 & 4.9 & 12.5 \\
\hline & $\mathrm{GH} 1$ & 152 & 24 & 15.8 & 277.9 & 328.5 & 3.9 & 6.5 & 16.7 \\
\hline
\end{tabular}

Note. N1, number of all grains; N2, number of coated grains; $P$, proportion of coated grains (\%); D1, average size of all grains ( $\mu$ m); D2, average size of coated grains ( $\mu m$ ); $R$, coated grain rounded $(\mu \mathrm{m})$; l, carbonate coat integrity; $T$, carbonate coat thickness $(\mu \mathrm{m})$.

(Figure 4D). With the increase in carbonate coat content, the roundness has a little variation (Figure 5A). The proportion mean values of carbonate coat covering the grain surface are from 4.9 to 7.7 (Table 2). EH1 and GH1 samples show low carbonate coat covering the grain surface, while other samples present high covering, especially the samples from the north of the lake (Figure 4C). The carbonate coat thickness of the samples present a mean value ranging from 11.4 to $18.8 \mu \mathrm{m}$ (Table 2), and are mostly less than $20 \mu \mathrm{m}$ (Figure 4E).

\section{DISCUSSION}

\section{Carbonate coat formation conditions}

Carbonate supersaturation is the main factor controlling the distribution of ooid sands (Rankey and Reeder, 2009). When the content of a certain mineral in water reaches saturation, precipitation can occur. By calculating the supersaturation value of calcium carbonate, Qinghai Lake and its lagoons are in a supersaturated state (LZIG, 1979). Chemically formed micritic carbonate minerals, like high-Mg calcite and aragonite, are about $1-15 \mu \mathrm{m}$ and are found in the upper $10 \mathrm{~m}$ water of Qinghai Lake and at the bottom of the lake, while they are not found in the lake shore (LZIG, 1979; Jin et al., 2013). Due to the strong hydrodynamic force at the lake shore (maximum wave height ranging from 1.8 to $3.3 \mathrm{~m}$ ), the microcrystalline carbonate was transported from the lake shore to the deep lake (LZIG, 1979; Zhang et al., 2018). Previous studies mainly collected the water in the deeper part of the lake to calculate the supersaturation value of calcium carbonate, and whether it has reached supersaturation for the lake shore (LZIG, 1979). According to the same method from LZIG (1979), we calculate the supersaturation value of calcium carbonate from the lake shore. Both Qinghai Lake and lagoon shores are greater than 1 (Table 1), although the values presented are different, indicating that calcium carbonate minerals can also be precipitated in the water of the lake shore. Moreover, it can be observed from the thin section that the sediments of the river are not carbonate coats, so the carbonate coats of the sediments in the lake and lagoons should be self-generated rather than imported from rivers. Therefore, part of the microcrystalline carbonate is transported to the deep lake by backwash from waves, and the other part covered with particles formed the carbonate coats.
Though strong hydrodynamics can take microcrystalline carbonate away from the lake shore to the deep lake, it is the essential condition to form the carbonate coats (Davies et al., 1978). Field studies and laboratory experiments suggest that agitation and supersaturation are two important conditions in the formation of ooids (Broecker and Takahashi, 1966; Davies et al., 1978). Sediments in this study are collected from the lake shores with strong hydrodynamics due to wind waves. Sands are introduced into turbulent supersaturated lake water by the strong hydrodynamics, and inorganic extremely small calcium carbonate crystal aggregates precipitate on their surfaces (Davies et al., 1978). Sedimentary particles with the same lake shore environment should have a similar behavior. However, not each particle has carbonate coats in the study area, and the highest percentage of particles with carbonate coats is only $43.1 \%$ at the lake shore (Table 2), which shows a complexity of the carbonate coat formation.

\section{Grain size effect on carbonate coat growth}

The carbonate coats have often been observed around mediumgrained sand, which are the coarser sand fraction in the sediments (Figure 4BandTable 1). Carbonate-coat growth requires three stages: suspension growth, resting, and sleeping stages (Davies et al., 1978). In the same sedimentary hydrodynamic condition, the different-sized grains experience different transport types, such as grain flow, saltation, and suspension (Hao et al., 2019). At the lake shore, where the large wave occurs, the strong hydrodynamics can stir up the coarse and fine sand leading to transient suspension. When the hydrodynamics become weaker, the coarser sand deposit on the lake bed, but the fine sand may be still suspended. So the fine sand only remains a short time on the lake bed, which means that the fine sand lack the resting and sleeping stages of the carbonate coat growth. Moreover, the carbonate coat growth needs to spend $95 \%$ of its life in the subsurface (Davies et al., 1978). In this area, the coarse sediment is mixed with fine sediment; the critical shear stress to mobilize the coarse sediment decreases due to exposure effects (McCarron et al., 2019). At the weak wave condition, the coarse sediment may be stirred up, and the calcium carbonate crystal aggregates will precipitate on their surfaces. This may be the reason why the carbonate coats are often observed on mediumgrained sand and rarely on fine sand in this study area. This also could explain the maximum carbonate-coated grain (mean grain size of $372.3 \mu \mathrm{m}$, Table 2) occurring in the northeast lake shore 

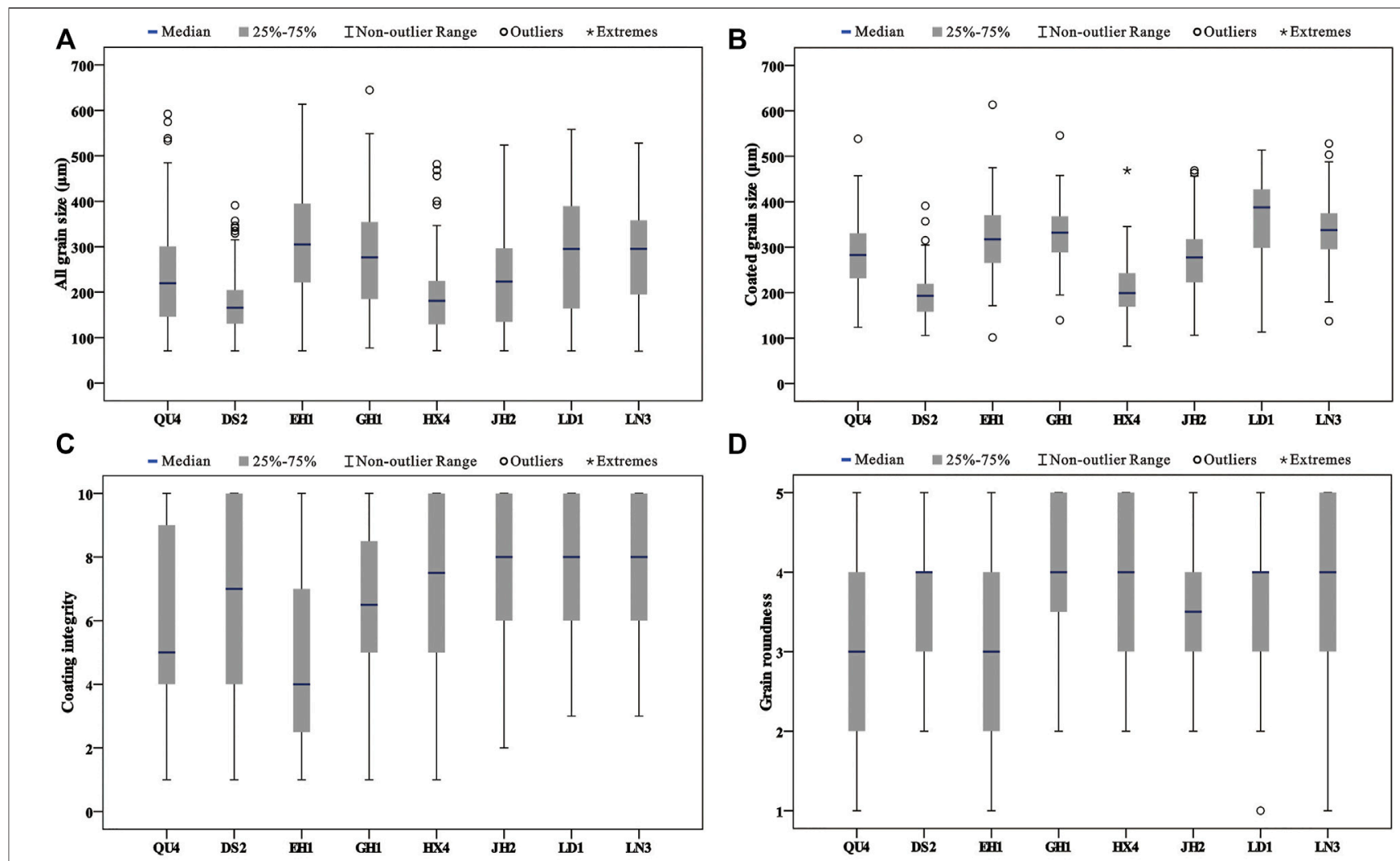

D
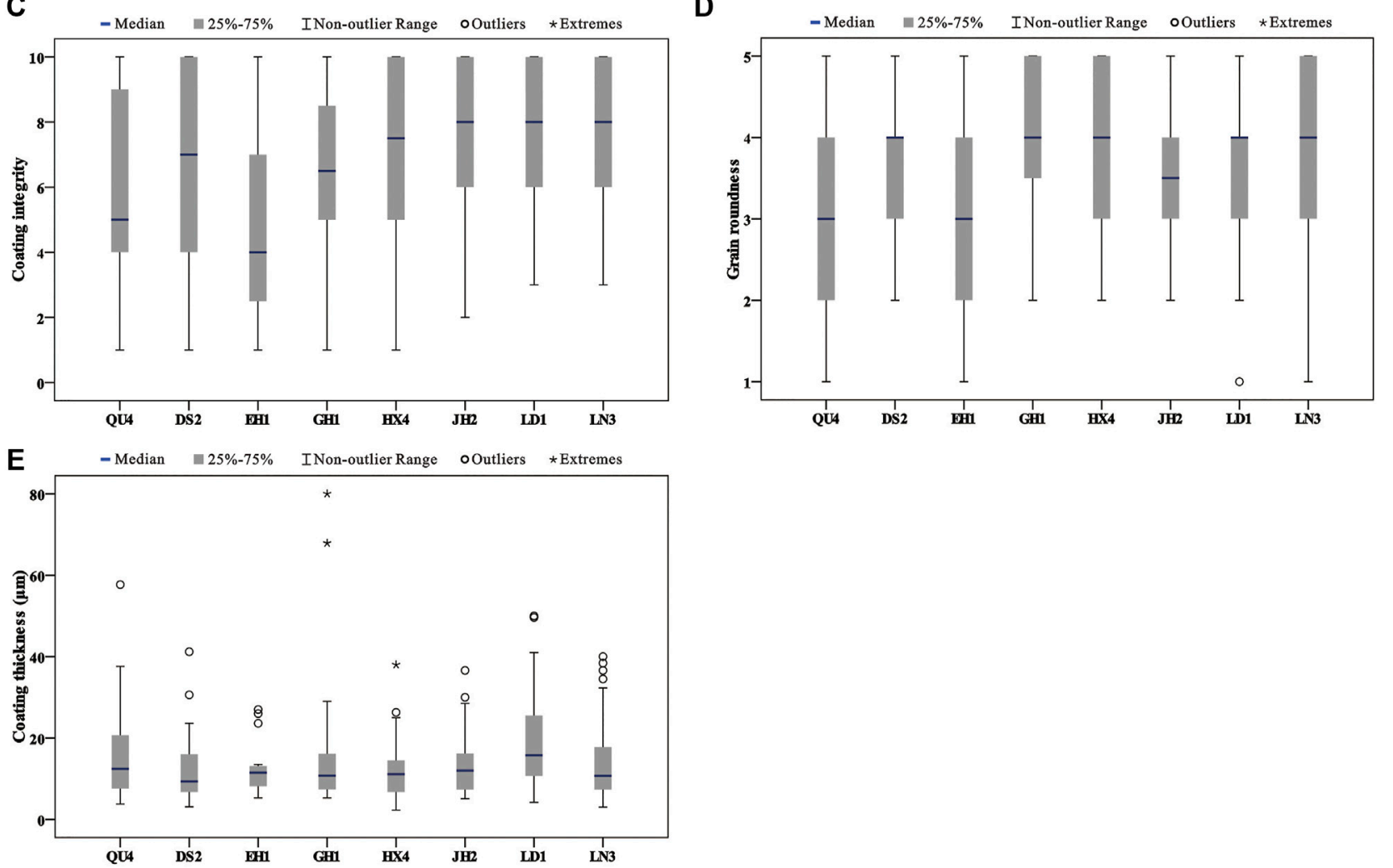

FIGURE 4|Results for grain and carbonate coat characteristics for the samples from the lake and lagoon. (A) Results for all grain sizes in the samples from the lake and lagoon. (B) Results for coated grain sizes in the samples from the lake and lagoon. (C) Results for coating integrity in the samples from the lake and lagoon. (D) Results for grain rounded in the samples from the lake and lagoon. (E) Results for coating thickness in the samples from the lake and lagoon.

with the strongest waves (Zhang et al., 2018). In a unimodal mixture, coarse sediment requires a high critical shear stress to be mobilized, while the fine unimodal sediment is readily mobile at a low critical shear stress (McCarron et al., 2019). If the lake shore is mainly composed of fine sediments and has strong hydrodynamic force, it is likely that the carbonate coats will not be produced due to the lack of resting and sleeping stages. On the contrary, if the sediments are mainly composed of coarse sediments, and the hydrodynamic force is very weak, it is likely that the carbonate coats will not form as the grains cannot be suspended. Therefore, carbonate coats can be produced only when the hydrodynamic force and the particle size are well matched. Due to the hiding- exposure effect, the relationship between the hydrodynamic force and the particle size will get more complex (McCarron et al., 2019).

\section{Hydrodynamic effect on carbonate coat distribution}

The agitation and supersaturation are two important conditions in the formation of the carbonate coats, so which factor leads to the difference of the proportions of particles with carbonate coats? In the two lagoons, the proportions of particles with carbonate coats are similar values, but the hydrochemical conditions show great distinction presenting the $\mathrm{Cl}-\mathrm{Na}$ type 


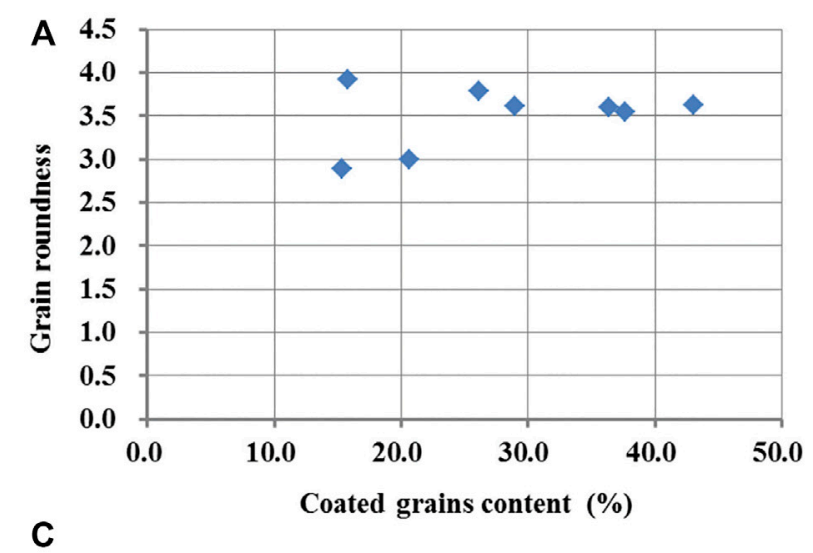

C

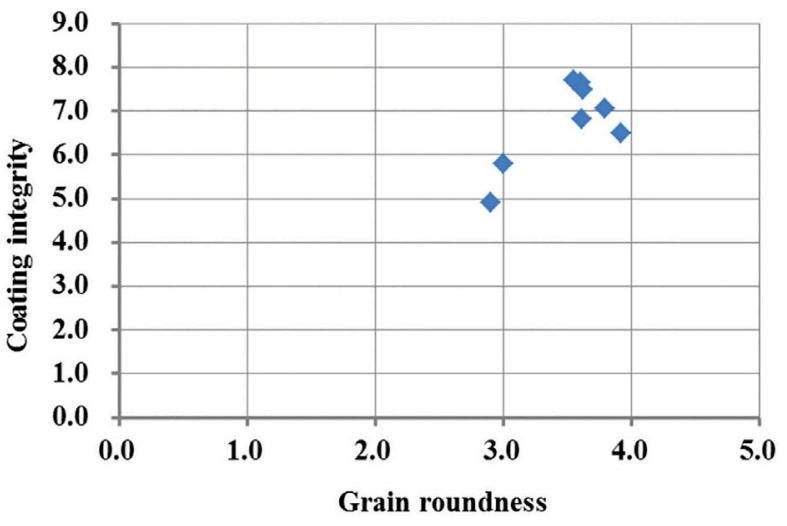

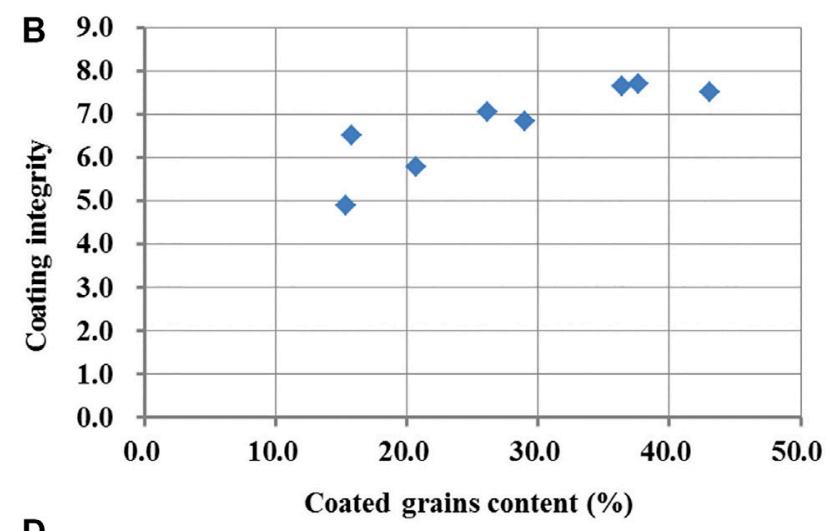

D

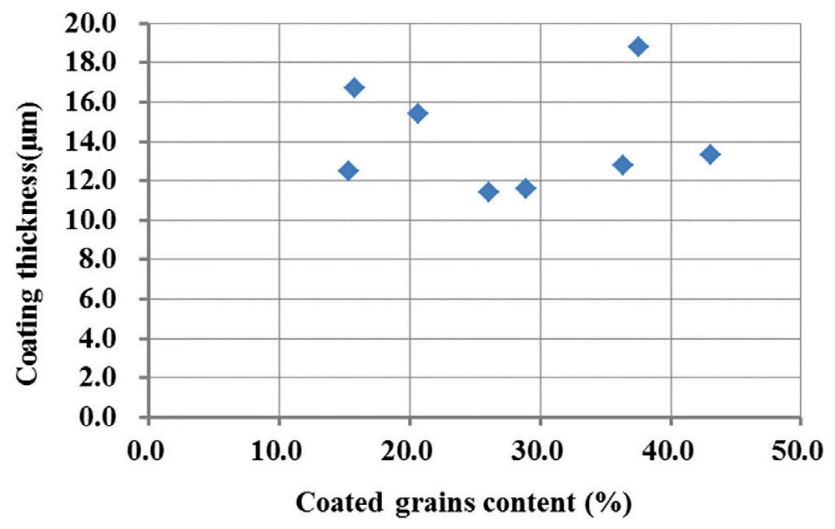

FIGURE 5| Correlation between coated grain content and carbonate coat characteristics. (A) Cross-plot of grain rounded versus coated grain content. (B) Crossplot of coating integrity versus coated grain content. (C) Cross-plot of coating integrity versus grain rounded. (D) Cross-plot of coating thickness versus coated grain content.

and $\mathrm{HCO}_{3}-\mathrm{Na}$ type (Figure 2andTables 1 and 2). For the lake, it shows a similar hydrochemical condition in the different lake shores, while the proportions of particles with carbonate coats present a difference (Figure 2andTables 1 and 2). Therefore, when the water in the different environments reaches carbonate supersaturation, the hydrochemical condition is not the major factor for controlling the distribution of carbonate coats.

The distribution of carbonate coats could be strongly linked to the location of the hydrodynamics. The fact that the two lagoons have similar small waves could explain the similar low proportions of particles with carbonate coats (Table 2). Lakes with stronger hydrodynamic forces have more proportions of particles with carbonate coats than lagoons (Table 2). The strength of waves varies at different locations of the lake (Zhang et al., 2018; Li, 2020; Hu et al., 2021). The north of the lake has an open lake surface and strong winds, which can produce larger waves, so the proportions of particles with carbonate coats in the north lake shore except the sample HX1 are higher than those in the south lake shore (Table 2). Sample HX1 is located in the lake bay of the northern lake with weak waves, so it has a lower proportion of particles with carbonate coats than the other north lake shore samples. There is a good correlation between the hydrodynamics and the proportions of particles with carbonate coats. Therefore, the hydrodynamics, and particularly the waves, are interpreted to be major factors controlling the distribution of carbonate coats in a similar sedimentary environment.

\section{Hydrodynamic effect on carbonate coat integrity}

The abundance of coated grains was compared with grain coating integrity (Figure 5B), which shows a strong correlation. This suggests that the stronger the hydrodynamic force is on the lake shore, the higher the integrity of coats. In observations from SEM, calcium carbonate crystal is generally found in the pit, on the lowcoated covering grains (Figure 3B). Carbonate coats are initially precipitated in pits on the grain surfaces. When the pits are filled, the calcium carbonate crystal starts to cover other grain surfaces. Under weak hydrodynamic conditions, coarse particles are easy to suspend due to exposure effect, but there is a short time stay in the suspended stage due to their weight, which leads to the calcium carbon crystal only settling in small pits. In the lake shores with strong hydrodynamic forces, coarse particles can be constantly suspended, and the rate of calcium carbon microcrystalline precipitation on the grain surface is greater, leading to the particles being completely covered by calcium carbon crystal. In addition, the particles with a higher integrity of 
precipitated carbonate coats also have the better roundness (Figures 3Dand5C). Because the rounded particles are easy to be rolled in turbulent conditions, it is more conducive to the precipitation of microcrystalline carbonate in the suspension stage.

\section{Hydrodynamic effect on carbonate coat thickness}

The carbonate coat thickness has a weak correlation with the coated grain content, displaying that the low-coated grain content has a larger coat thickness (Figure 5D). On the lake shore with less-coated grain content, the carbonate is generally developed in pits of particles and covers less of the particle surface, and the thickness of the completely covered carbonate coats present is thin (Figures 3B, C). When measuring the carbonate coat thickness in the lake shore with the low-coated grain content, the depth of most pits was measured representing the thickness of the carbonate coats due to it rarely completely covering the grain surface, which leads to a large thickness of the carbonate coats in this lake shore. In the lake shore with more coated grain content, there are more particles completely covered with carbonate coats (Figure 3D), and the statistical thickness is mostly the thickness of the carbonate rings, not the depth of the pits. Different statistical methods lead to a higher carbonate coat thickness values in the lake shore with the low-coated grain content. If the thickness of the completely covered carbonate coats were only counted in all the samples, there should be a good positive correlation between the carbonate coat thickness and the coated grain content. The particles from the lake shore with strong waves can be stirred up many times and undergo several carbonate microcrystalline precipitation cycles, resulting in an increase in carbonate coat thickness. So, the hydrodynamic force on the lake shore can affect the thickness of the carbonate coats. When ooids are near a dynamic equilibrium size dependent upon precipitation and abrasion, ooid growth would cease (Trower et al., 2017).

Beach rock deposits exist in the shoreline of Qinghai Lake, and microorganisms are found in the carbonate cement of beach rock (Li, 2003; Chen et al., 2019). The grain cortices also develop in the beach rocks, which are disposed radially. Radial ooids are generally formed in quiet water with the bacteria (Davies et al., 1978). Therefore, microorganisms play an important role in the formation of cortices in this beach rocks. Recent studies have shown that microorganisms are found more and more important in the ooid formation (Diaz et al., 2015; Diaz et al., 2017). In this study, the ooids show tangential differences with those in the beach rocks, and bacteria or EPS are not observed within ooid cortices by SEM. Therefore, whether bacteria are involved in the formation of ooids needs more analytical methods to study in the future, but it is certain that hydrodynamic forces play a great role in carbonate grain coat distribution, integrity, thickness, and ooid grain size.

\section{CONCLUSION}

1. Qinghai Lake has the hydrochemical and hydrodynamic conditions for the formation of ooids. Carbonate coats are found in different lake shores and lagoons, which show thin cortices and even some particles with discontinuous or patchy coatings.

2. Carbonate-coated grain content presents variations in different locations in the lake. The hydrochemical condition is not the major factor but the hydrodynamics, and particularly, the wave characters seem to control the distribution of carbonate coats in the similar sedimentary environment.

3. The carbonate coats are often observed on medium-grained sand and rarely on fine sand in this study area, and the maximum carbonate-coated grain occurred under the strongest waves. Carbonate coats can be produced only when the hydrodynamic force and particle size are well matched.

4. The strong hydrodynamic force on the lake shore induces higher integrity and thickness of sand coats. Hydrodynamics is not only one of the important conditions for the formation of the carbonate coats but also has a significant effect on carbonate grain coat distribution, integrity, thickness, and carbonate coat grain size.

5. Bacteria or EPS are not observed within ooid cortices. The bacteria are not the main factor, but hydrodynamic forces play a great role in the formation of ooids in this study area.

\section{DATA AVAILABILITY STATEMENT}

The original contributions presented in the study are included in the article/Supplementary Material. Further inquiries can be directed to the corresponding authors.

\section{AUTHOR CONTRIBUTIONS}

LH contributed to the design of the study and wrote the manuscript. HT analyzed the result of the experiments. SL performed the statistical analysis and collected the samples. XM finished the experiments on the thin sections. HJ finished the experiments on the SEM. JQ finished the experiments on the chemical constituents. All authors contributed to the manuscript revision, and read and approved the submitted version.

\section{FUNDING}

The study was supported by the National Natural Funding Science Foundation of China (Grant Nos. 41502142, 41772142) and the Second Tibetan Plateau Scientific Expedition and Research Program (STEP) (No. 2019QZKK0704).

\section{ACKNOWLEDGMENTS}

We would like to thank Professor Chengjun Zhang, the Chief Editor, and the reviewers for their valuable comments. The Yl station dataset is provided by National Tibetan Plateau Data Center (http://data.tpdc.ac.cn). 


\section{REFERENCES}

An, Z., Colman, S. M., Zhou, W., Li, X., Brown, E. T., Jull, A. J. T., et al. (2012). Interplay between the Westerlies and Asian Monsoon Recorded in lake Qinghai Sediments since 32 Ka. Sci. Rep. 2, 619. doi:10.1038/srep00619

Ariztegui, D., Plée, K., Farah, R., Menzinger, N., and Pacton, M. (2012). Bridging the gap between Biological and Sedimentological Processes in Ooid Formation: Crystalizing F. A. Forel's Vision. Arch. Sci. 65, 93-102.

Ball, M. M. (1967). Carbonate Sand Bodies of florida and the bahamas. J. Sediment. Petrol. 37, 556-591. doi:10.1306/74d7171c-2b21-11d7-8648000102c1865d

Beukes, N. J. (1983). "Ooids and Oolites of the Proterophytic Boomplaas Formation, Transvaal Supergroup, Griqualand West, South Africa," in Coated Grains. Editor T.M. Peryt (Berlin: Springer-Verlag), 199-214. doi:10.1007/978-3-642-68869-0_18

Broecker, W. S., and Takahashi, T. (1966). Calcium Carbonate Precipitation on the Bahama Banks. J. Geophys. Res. 71, 1575-1602. doi:10.1029/jz071i006p01575

Chen, J., Jiang, Z., Zhang, W., Liu, C., and Xu, W. (2019). The Petrological Characteristics and Formation Mechanism of Lake Beachrock in Lake Qinghai. J. Lake Sci. 31 (6), 1783-1796. doi:10.18307/2019.0623

Davies, P. J., Bubela, B., and Ferguson, J. (1978). The Formation of Ooids. Sedimentology 25, 703-730. doi:10.1111/j.1365-3091.1978.tb00326.x

Davaud, E., and Girardclos, S. (2001). Recent freshwater ooids and oncoids from western Lake Geneva (Switzerland): Indications of a common organically mediated origin. J. Sediment. Res. 71, 423-429. doi:10.1306/2DC40950-0E4711D7-8643000102C1865D

Davies, P. J., and Martin, K. (1976). Radial Aragonite Ooids, Lizard Island, Great Barrier Reef, Queensland, Australia. Geol 4, 120-122. doi:10.1130/00917613(1976)4<120:raolig >2.0.co;2

Diaz, M. R., Eberli, G. P., Blackwelder, P., Phillips, B., and Swart, P. K. (2017). Microbially Mediated Organomineralization in the Formation of Ooids. Geology 45, 771-774. doi:10.1130/g39159.1

Diaz, M. R., and Eberli, G. P. (2019). Decoding the Mechanism of Formation in marine Ooids: a Review. Earth-Science Rev. 190, 536-556. doi:10.1016/j. earscirev.2018.12.016

Diaz, M. R., Swart, P. K., Eberli, G. P., Oehlert, A. M., Devlin, Q., Saeid, A., et al. (2015). Geochemical Evidence of Microbial Activity within Ooids. Sedimentology 62, 2090-2112. doi:10.1111/sed.12218

Duguid, S. M. A., Kyser, T. K., James, N. P., and Rankey, E. C. (2010). Microbes and Ooids. J. Sediment. Res. 80, 236-251. doi:10.2110/jsr.2010.027

Dupraz, C., and Visscher, P. T. (2005). Microbial Lithification in marine Stromatolites and Hypersaline Mats. Trends Microbiol. 13, 429-438. doi:10. 1016/j.tim.2005.07.008

Fan, J., Gijbels, I., and Ma, B. (1994). Evolution of Recent Environment in Qinghai Lake and its Prediction. Beijing: Science Press, 1-12. doi:10.1007/978-1-48993150-4_1

Halley, R. B. (1977). Ooid Fabric and Fracture in the Great Salt Lake and the Geologic Record. J. Sedim. Petrol. 47, 1099-1120. doi:10.1306/212f72ed-2b24$11 \mathrm{~d} 7-8648000102 \mathrm{c} 1865 \mathrm{~d}$

Hao, L., Tao, H., Guo, R., Mou, W., Tian, B., and Ma, X. (2019). Hydrodynamic Evolution from Quartz Microtextures of a beach ridge in Qinghai Lake, China. Sediment. Geology. 389, 13-25. doi:10.1016/j.sedgeo.2019.05.008

Harris, P. M., Halley, R. B., and Lukas, K. J. (1979). Endolith Microborings and Their Preservation in Holocene-Pleistocene (Bahama-Florida) Ooids. Geol 7, 216-220. doi:10.1130/0091-7613(1979)7<216:ematpi>2.0.co;2

Harris, P. M., Purkis, S. J., and Ellis, J. (2011). Analyzing Spatial Patterns in Modern Carbonate Sand Bodies from Great Bahama Bank. J. Sediment. Res. 81, 185-206. doi:10.2110/jsr.2011.21

Hu, G., Dong, Z., Zhang, Z., Yang, L., Hao, L., Hesp, P., et al. (2021). Wind Regime and Aeolian Landforms on the Eastern Shore of Qinghai Lake, Northeastern Tibetan Plateau, China. J. Arid Environments 188, 104451. doi:10.1016/j. jaridenv.2021.104451

Jin, Z. D., Zhang, F., Li, F. C., Chen, L. M., Xiao, J., and He, M. Y. (2013). Seasonal and Interannual Variations of the lake Water Parameters and Particle Flux in Lake Qinghai: A Time-Series Sediment Trap Study (In Chinese). J. Earth Environ. 4, 1306-1313. doi:10.7515/JEE201303002

Kahle, C. F. (1974). Ooids from Great Salt Lake, Utah, as an Analogue for the Genesis and Diagenesis of Ooids in marine Limestones. J. Sedim. Petrol. 44, 30-39. doi:10.1306/74d7296e-2b21-11d7-8648000102c1865d
Kump, L. R., and Hine, A. C. (1986). "Ooids as Sea-Level Indicators," in Sea-Level Research: A Manual for the Collection and Evaluation of Data. Editor O. van de Plassche (Norwich: Geo Books), 175-193. doi:10.1007/978-94009-4215-8_7

Li, F., Yan, J., Algeo, T., and Wu, X. (2013). Paleoceanographic Conditions Following the End-Permian Mass Extinction Recorded by Giant Ooids (Moyang, South China). Glob. Planet. Change 105, 102-120. doi:10.1016/j. gloplacha.2011.09.009

Li, J., and Fang, X. (1999). Uplift of the Tibetan Plateau and Environmental Changes. Chin. Sci. Bull. 44, 2117-2124. doi:10.1007/bf03182692

Li, X.-Y., Xu, H.-Y., Sun, Y.-L., Zhang, D.-S., and Yang, Z.-P. (2007). Lake-level Change and Water Balance Analysis at Lake Qinghai, West China during Recent Decades. Water Resour. Manage. 21, 1505-1516. doi:10.1007/s11269006-9096-1

Li, X., Yang, X., Ma, Y., Hu, G., Hu, X., Wu, X., et al. (2018). Qinghai Lake Basin Critical Zone Observatory on the Qinghai-Tibet Plateau. Vadose Zone J. 17, 180069. doi:10.2136/vzj2018.04.0069

Li, X. Y., Ma, Y. J., Huang, Y. M., Hu, X., Wu, X. C., Wang, P., et al. (2016). Evaporation and Surface Energy Budget over the Largest High-Altitude saline lake on the Qinghai-Tibet Plateau. J. Geophys. Res. Atmospheres 121 (18), 10470-10485. doi:10.1002/2016jd025027

Li, X. Y. (2020). Qilian Mountains Integrated Observatory Network: Dataset of Qinghai Lake Integrated Observatory Network (An Observation System of Meteorological Elements Gradient of Yulei Station on Qinghai lake, 2019). Beijing: National Tibetan Plateau Data Center. doi:10.11888/Meteoro.tpdc. 270732

Li, Y. C. (2003). Comparing Researchbeachrock in the South of Fujian Province and Lake Qinghai. J. Quanzhou Normal Univ. Nat. Sci. 21 (4), 43-47. doi:10. 16125/j.cnki.1009-8224.2003.04.011

Liu, X., Chen, X., Tostevin, R., Yao, H., Han, K., Guo, H., et al. (2021). Postdepositional Modification of Carbonate Ooids by Sulfate-Reducing Bacteria: Evidence from the Lower-Middle Jurassic, Tethyan Himalayas of Southern Tibet. Sediment. Geology. 426, 106027. doi:10.1016/j.sedgeo.2021.106027

Lu, C., Li, F., Oehlert, A. M., Li, J., and Zou, H. (2020). Reconstructing Paleoceanographic Conditions during the Middle Ediacaran: Evidence from Giant Ooids in South China. Precambrian Res. 351, 105945. doi:10.1016/j. precamres.2020.105945

LZIG (1979). General Investigation Report of Qinghai Lake. Beijing: Science Press, $1-270$.

McCarron, C. J., Van Landeghem, K. J. J., Baas, J. H., Amoudry, L. O., and Malarkey, J. (2019). The Hiding-Exposure Effect Revisited: A Method to Calculate the Mobility of Bimodal Sediment Mixtures. Mar. Geology. 410, 22-31. doi:10.1016/j.margeo.2018.12.001

Opdyke, B. N., and Wilkinson, B. H. (1990). Paleolatitude Distribution of Phanerozoic marine Ooids and Cements. Palaeogeogr. Palaeoclimatol. Palaeoecol. 78, 135-148. doi:10.1016/0031-0182(90)90208-o

Pacton, M., Ariztegui, D., Wacey, D., Kilburn, M. R., Rollion-Bard, C., Farah, R., et al. (2012). Going Nano: a New Step toward Understanding the Processes Governing Freshwater Ooid Formation. Geology 40, 547-550. doi:10.1130/ g32846.1

Piper, A. M. (1944). A Graphic Procedure in the Geochemical Interpretation of Water-Analyses. Trans. AGU 25 (6), 914-928. doi:10.1029/tr025i006p00914

Plée, K., Ariztegui, D., Martini, R., and Davaud, E. (2008). Unravelling the Microbial Role in Ooid Formation-Results of an In Situ experiment in Modern Freshwater Lake Geneva in Switzerland. Geobiology 6, 341-350. doi:10.1111/j.1472-4669.2007.00140.x

Popp, B. N., and Wilkinson, B. H. (1983). "Holocene Lacustrine Ooids from Pyramid Lake, Nevada," in Coated Grain. Editor T. M. Peryt (Berlin: SpringerVerlag), 141-153. doi:10.1007/978-3-642-68869-0_12

Rankey, E. C., and Reeder, S. L. (2009). Holocene Ooids of Aitutaki Atoll, Cook Islands, South Pacific. Geology 37, 971-974. doi:10.1130/g30332a.1

Rankey, E. C., Riegl, B., and Steffen, K. (2006). Form, Function and Feedbacks in a Tidally Dominated Ooid Shoal, Bahamas. Sedimentology 53, 1191-1210. doi:10. 1111/j.1365-3091.2006.00807.x

Simonson, B. M., and Jarvis, D. G. (1993). "Microfabrics of Oolites and Pisolites in the Early Precambrian Carawine Dolomite of Western Australia," in Carbonate Microfabrics. Editors R. Rezak and D. Lavoieeds (Heidelberg: Springer-Verlag), 227-237. doi:10.1007/978-1-4684-9421-1_17 
Sipos, A. A., Domokos, G., and Jerolmack, D. J. (2018). Shape Evolution of Ooids: a Geometric Model. Sci. Rep. 8, 1758. doi:10.1038/s41598-01819152-0

Sumner, D. Y., and Grotzinger, J. P. (1993). Numerical Modeling of Ooid Size and the Problem of Neoproterozoic Giant Ooids. J. Sediment. Petrol. 63, 974-982. doi:10.1306/d4267c5d-2b26-11d7-8648000102c1865d

Trower, E. J., Lamb, M. P., and Fischer, W. W. (2017). Experimental Evidence that Ooid Size Reflects a Dynamic Equilibrium between Rapid Precipitation and Abrasion Rates. Earth Planet. Sci. Lett. 468, 112-118. doi:10.1016/j.epsl.2017. 04.004

Tucker, M. E., and Wright, V. P. (1990). Carbonate Sedimentology. Oxford: Blackwell Science, 482.

Wanless, H. R., and Tedesco, L. P. (1993). "Comparison of Oolitic Sand Bodies Generated by Tidal vs Wind-Wave Agitation," in Mississippian Oolites and Modern Analogs. 35. Editors B.D. Keith and C.W. Zuppann (Tulsa, Oklahoma: AAPG Stud. Geol), 199-225. doi:10.1306/st35571c15

Wilkinson, B. H., Pope, B. N., and Owen, R. M. (1980). Nearshore Ooid Formation in a Modern Temperate Region Marl Lake. J. Geology. 88, 697-704. doi:10.1086/ 628555

Yuan, Z., Zhong, X. G., and Ye, S. J. (1990). The Core Evolution of a Globular Cluster Containing Massive Black Holes. Astrophys Space Sci. 168, 233-241. doi:10.1007/bf00636869
Zhang, Y., Hu, C., Wang, M., Ma, M., Wang, X., and Jiang, Z. (2018). A Quantitative Sedimentary Model for the Modern Lacustrine beach Bar (Qinghai Lake, Northwest China). J. Paleolimnol. 59, 279-296. doi:10.1007/ s10933-016-9930-2

Conflict of Interest: The authors declare that the research was conducted in the absence of any commercial or financial relationships that could be construed as a potential conflict of interest.

Publisher's Note: All claims expressed in this article are solely those of the authors and do not necessarily represent those of their affiliated organizations, or those of the publisher, the editors, and the reviewers. Any product that may be evaluated in this article, or claim that may be made by its manufacturer, is not guaranteed or endorsed by the publisher.

Copyright (c) $2022 \mathrm{Hao}$, Tao, Li, Ma, Ji and Qiu. This is an open-access article distributed under the terms of the Creative Commons Attribution License (CC BY). The use, distribution or reproduction in other forums is permitted, provided the original author(s) and the copyright owner(s) are credited and that the original publication in this journal is cited, in accordance with accepted academic practice. No use, distribution or reproduction is permitted which does not comply with these terms. 